\title{
NÂBî'NIN iKi GAZELINDE KALB'DEN ANLAMA GIDEN YOL
}

\section{The Way From the Art of Kalb to Meaning in Nabi's Two Lyrics}

\section{Dr. ibrahim GÜLTEKiN*}

ÖZ

Klasik Türk edebiyatı kuralları, estetik unsurları, muhtevası ve kültürel zenginlikleri ile islam medeniyet dairesinin zemininde oluşarak altı asırlık bir süreçte gelişmesini sürdürmüştür. $\mathrm{Bu}$ edebiyata mensup sanatkârlar, içinde yer aldıkları medeniyetin ortak üslubunu benimserken şahsi olma başarısını da gösterebilmişlerdir. Bu itibarla; sanatçının melekesi, aldığı eğitim, yetiştiği çevre, içinde yer aldığı sosyo-kültürel ortam, toplumsal statü vb. faktörler onun şahsi üslubunun oluşmasında önemli olmaktadır.

Araştırmacılar tarafından hikemî şiirin öncüsü/önemli bir temsilcisi kabul edilen Nâbînnin sanat anlayışının oluşmasında da yukarıda ifade ettiğimiz hususların etkili olduğu bir gerçektir. Nâbînin şiirlerinin muhtevasına ve onun üslubuna, yaşadığı yüzyılın sorunlarının; sosyal, kültürel, siyasal, ekonomik ve ahlakî çözülmelerin damgasını vurduğunu söyleyebiliriz. Nitekim Nâbîyi farklı kılan da çağının sıkıntılarını şiir diliyle ifade etmesidir. $\mathrm{O}$, işlediği konular ve bu konuları işleyiş biçimi ile klasik Türk şiirine yeni bir soluk getirmiş, çağının sanatkârları ve kendisinden sonra gelenler için örnek alınan bir şair olmuştur.

Bu çalıșmada Nâbînnin, "bozundısıdur" redifli iki gazeli, gazellerin her beytinde anlam ile bütünleșen kalb sanatı bağlamında incelenip değerlendirilmiştir. Çalışmada adı geçen gazellerin seçilmesinin sebebi bu gazellerin Nâbînin sanat anlayışını ve

\section{ABSTRACT}

The rules of classical Turkish literature, aesthetic elements, contents and cultural riches, on the basis of the Islamic civilization over a period of six centuries continued its development.While artists belonging to this literature were adopting a common style of civilization where they are located in, they were also able to show the distinction of being personally.ln this respect, the training, environment, socio-cultural environment that the artists took place in and social rank of artists' are important in the formation of personal style.

$\mathrm{Nabi}$, who is agreed as the pioneer of eracular poetry and adopted an important representative of this poetry by the researchers, was influenced issues mentioned above in the formation of the concepts of his art.We can say that, the problems experienced in the century, social, cultural, political, economic and moral disintegrations hit the mark of Nabi's contents of poems and his style.Indeed, what makes Nabi different is that the problems of the era was expressed by Nabi in the language of poetry. He, the subjects dealth with these issues and mode of operation of these subjects, brought a new breath to classical Turkish poetry and became a sample poet for craftsmen of his era and also for those who come after him.

In this study, Nabi's two lyric that has "bozundisıdur" rhyme, was evaluated in the context of " art of kalb ". The reason for choosing the mentioned lyric in this study is because these lyrics reflect the understan-

**Bülent Ecevit Üniversitesi Fen Edebiyat Fakültesi Türk Dili ve Edebiyatı ibrahim. gultekin@ karaelmas.edu.tr 
üslubunu birçok yönüyle yansıtması dolayısıyladır. Osmanlının gerileme döneminde yaşayan Nâbî, gazelleri için seçtiği "bozındısıdur" redifiyle kalb sanatını birleştirerek hüner vadisini parıltılı hikmet incileri ile bezemiştir.

Anahtar Sözcükler: Nâbî, hüner, kalb, sanatı, hikmet ding of art and style of Nabi's in many aspects.Nabi, living in the Ottoman Empire during the downturn, by choosing "bozundisidur " rhyme for his lyrics and integrating them with "art of kalb", showed his skill in this trick valley.

Key Words: Nabi, Skill, Art of Kalb, Mystery

\section{Giriş}

Klasik Türk edebiyatı, geleneği ve teşrifatı olan bir sanat anlayışını benimser. "Divan edebiyatında gelenek, şiirin şekli yönünü değişmez ve dışına çıkılamaz surette tespit ettiği gibi muhtevayı da belirli bir daire içinde sınırlamıştır. Her şairin gelenekçe belirlenmiş ve mutlaka seçip kabul etmek mecburiyetinde olduğu önceden hazır konu ve duygular, yerlerine başkalarının konulamayacağı motiflerle sabitleşmiş bir imaj sistemi vardır." (Akün 1994: 413). Böyle bir anlayışın ve sistemin içinden seslenen bir sanatkârı diğerlerinden farklı kılan hususiyetler, sanatkârın zevk-i selimi, kişiliği, eğitimi, yetiştiği çevre ve bu çevrenin sosyal, kültürel, siyasal, ekonomik ve coğrafi şartları, toplumsal çevresi ve statüsü, dönemin sanat algısının düzeyi ve döneme damgasını vuran üslup özellikleri gibi unsurlardır. Sanatçının zevk-i selimi, dönemin şiir dili, sanat algısı ve üslubundaki farklılığı ve değişmeyi göstermesi yönüyle iki ayrı yüzyıldan şairi bu çerçevede örnek olarak verebiliriz.

Şiir dilindeki değişme/gelişme çizgisine paralel olarak aynı geleneğin içinden seslenmelerine rağmen şairlerin dile ait malzemeyi kullanmalarında yüzyıllara göre farklılık ortaya çıkmaktadır. Bu durum kişisel üslup ve devir üslubu ile açıklanır. "Osmanlı şiirinin kurucularından sayılan” (Muallim Nâci 1995: 316). Necatî (öl. 1509), "Türkçe kelimeleri, tabirleri ve atasözlerini bütün imkânlarıla kullanan bir şairdir." (Şentürk ve Kartal 2011: 222). "Latîfi onun Osmanlı şairlerinin yüz suyu olduğunu, Asşık Çelebi de iran şairlerinin bizde, kendileri ayarında şair bulunmadığ yolunda yaralayıcı sözler söylemelerinden bizi Necatî Bey'in kurtardığını ifade ederek, onu ilk orijinal şair olarak göstermiştir." (Şentürk ve Kartal: 2011, 222). Necatînnin şiir dili şairin şahsi üslubunu ve dönemin dilini yansıtmakla birlikte bu dilin şekillenmesinde şüphesiz Türk şiirine yöneltilen "taklit" eleştirisinin de payı olduğu söylenebilir.

Necatînnin şiir dilini göstermesi bakımından bir gazelinden iki beyit örnek olarak verilmiştir.

Lâle-hadler gülşende neler itmediler Servi yürütmediler goncayı söyletmediler (...)

Ey Necatî yürü sabr eyle elinden ne gelir Hûblar cevr ü cefâyı kime ögretmediler (Tarlan 1992: G. 198) 
Klasik Türk edebiyatında Sebk-i Hindî şiir anlayışının en önemli temsilcilerinden olan 17. yüzyıl şairi Nailî (öl. 1666) için ise artık Türk şiirindeki özgünlüğü ispat etme gibi bir iddia söz konusu değildir. Dolayısıyla şiir vadisinde gelinen nokta sebk-i hindînin de etkisiyle kendisini özellikle Farsça-Arapça kelimelerin ve zincirleme tamlamaların kullanıldığı bir şiir diline bırakır.

Tercemân-ı güft-gûy-ı râz-ı halvetgâh-ı dil

Mahrem-i şâhenşeh-i kudsî-cenâb-ı mahşeriz (ipekten 1990: G. 161)

Vâ-sûhtegân-ı harem-i ka'be-i ışkız

Peygûle-i gam-hâne-i dil meskenimizdir (ipekten 1990: G. 113)

Sanatkârlık kabiliyeti dışında devir üslubunun, dönemin sanat algısının, siyasi, sosyokültürel, ekonomik etkilerin ve şairin yaşadığı coğrafya ile yetişme çevresinin onun şiir dilini ve üslubunu belirlemede önemli değişkenler olduğuna dair klasik Türk edebiyatının gelişme çizgisinde birçok örnek verilebilir. Bu çalışmanın konusunu tam da bu özellikleri ile klasik Türk şiiri vadisinde farklı bir yol açan ya da bir şekilde var olan yolu şiir dünyasının merkezine oturtan kendi döneminde ve kendisinden sonra muakkipleri olan Nâbînnin, "bozundısıdur" adlı iki gazelindeki hikmet, düşünce ve toplumsal eleştirinin "kalb" sanatı yoluyla dile getirilişi teşkil etmektedir.

Şiirlerin incelenmesine geçilmeden önce Nâbînin şiirinin oluşmasında nelerin etkili olduğu ve "bozundısıdur" redifli gazellerinin merkezinde yer alan "kalb" sanatının ne olduğu kısaca ele alınacaktır.

\section{Nâbî ve 17. Yüzyılda Osmanlı Devletinin Görünümü}

17. yüzyılın ve klasik Türk şiirinin en önemli şairlerinden olan Nâbî (öl. 1712) de her sanatkâr gibi hazır bir kültürün içine doğmuştur. Nâbînnin yaşadığı çağın Osmanlı Devleti, sosyal, siyasal, ekonomik, kültürel ve toplumsal ahlâk boyutuyla çok yönlü bir bozulma ve çözülme dönemine karşılık gelir.

17. yüzyıl Osmanlı Devleti için tam bir çözülme dönemidir. Devlet otoritesi zayıflamış, sosyal, siyasi ve ekonomik sıkıntılar merkezden başlamak üzere ülkenin en uç köşesine kadar yayılmıştır. Devlet yönetiminde liyakat yerine sadakatin öne çıkması, entrika hastalığının devlet idaresini örümcek ağı gibi sarması, bilim dünyasında beşik ulemalığı gibi ilmî gelişmeyi zayıflatan unsurların hâkim olması, kaht-ı rical denilen yetişmiş adam kıtlı̆̆ı, Yeniçeri ve Celali isyanları, uzun süre devam eden ancak zaferle sonuçlanmayan savaşlar ve bu savaşların ekonomik, sosyal, siyasi hayat üzerindeki olumsuz etkileri, çöküşün en keskin dönemeçlerinden sayılan Viyana bozgunu (1683) ve toprak kayıplarıyla sonuçlanan Karlofça Antlaşması (1699) Nâbînnin yaşadığı dönemin genel manzarasıdır (Kurnaz 2009; Karahan 1987: 49; Mengi 1991; Mengi 2000: 174-197; Kortantamer 1984: 83-116). 
Böyle bir dönemde yetişen Nâbî, klasik Türk edebiyatı geleneği içinde kalmak suretiyle' şiirden hareketle topluma ayna tutmuştur. Bu aynada Osmanlı siyasi hayatındaki çözülme ve toplumsal hayatta görülen bozulma birtakım yönleriyle gözler önüne serilir. Bu şiir anlayışıyla Nâbî, klasik Türk edebiyatında hikemî tarzın öncüsü ya da en önemli temsilcisi kabul edilir.

"Denebilir ki Nâbî, çağının huzursuzluk ve kararsızlıkları, hükümet yönetiminden başlayarak çeşitli meslek erbabı arasında yaygınlaşan zulüm, hile, rüşvet, mal ve menala aşırı rağbet, riyakârlık, her işte menfaata bağlılık gibi kötü huyların toplumu kemirmesi karşısında: fikir ve hikmetin kanatları gölgesinde -manen olsun- rahat dağdağasız yaşamak iç arzusuyla dolu bir şahsiyettir. Şiirlerinde: bazen eleştirilerde bulunup ferahlamak, bazen şikâyetlerle gönlündekileri etrafinda bulunanlara duyurmak, bazen tevekkülle olayları göğüslemek, bazen hikmetle yoğrulmuş düşünce ve görüşlerle onlara ibretle bakmak ve nihayet bazan da insanın aslında güçsüz zayıf bir mahluk olduğunun derin hassasiyeti ve aczi içinde teslimiyetle hafif bir isyan arasında gidip gelmek -hemen hemen- göze çarpan özelliklerin ön safinda yer almaktadır." (Karahan 1987: 56).

'Mustafa İsen, hem estetik anlayış hem de muhteva yönünden divan şiirine getirdiği yenilikler bakımından Nâbî̀yi geleneğe direnen şairlerden kabul eder.

ìsen Mustafa (1997). "Divan Edebiyatında Geleneğe Direnenler I Nâbî", Ötelerden Bir Ses, An kara: Akçă̆ Yayınları. s. 244-250.

${ }^{2}$ Nâbînnin şiir dünyasının toplumsal eleştiri ve hikemî yönü doçentlik tezi başta olmak üzere kitap ve makale boyutunda birçok araştırmacı tarafından dile getirilmiştir. Bu çalışmalardan bazıları şunlardır:

Mengi, Mine. Divan Şiirinde Hikemî Tarzın Büyük Temsilcisi Nâbî, 2. Baskı, Ankara: Atatürk Kültür, Dil ve Tarih Yüksek Kurumu Atatürk Kültür Merkezi Yayınları, 199ı.

Mengi, Mine. "Çağının Insanı Olarak Nâbı̂”, “Hikemî Şiir ve Nâbî", Divan Şiiri Yazıları, s. 200219, Ankara: Akçă̆ Yayınları, 2010.

Karahan, Abdülkadir. Nâbî, s. 49-78, Ankara: Kültür ve Turizm Bakanlığı, 1987.

Kortantamer, Tunca. Nâbînnin Osmanlı İmparatorluğunu Eleştirisi, Tarih İncelemeleri Dergisi II, İzmir, s. 83-116, 1984.; Şair Nâbî. (Editör Ali Fuat Bilkan), s. 109-143, Ankara: T.C. Kültür ve Turizm Bakanlı̆̆ı, 2012.

Bilkan, Ali Fuat. “Nâbînnin Gazellerinde Görme Biçimleri”, Osmanlı Şiiri’ne Modern Yaklaşımlar, s. 43-56, ìstanbul: L\&M, 2006.

Bilkan, Ali Fuat. Nâbî Hayatı Sanatı Eserleri, Ankara: Akçağ Yayınları, 2010.

Kurnaz, Cemal. "Nâbî̀de Belge-sel Redifler", s. 63-68, (Editör Ali Bakkal), Şair Nâbî Sempozyumu, Şanlıurfa 13-15 Kasım 2009.

ülgener, Sabri. iktisadi Çözülmenin Ahlâk ve Zihniyet Dünyası, İstanbul: Derin Yayınları, 2006. Yorulmaz, Hüseyin. Divan Edebiyatında Nâbî Ekolü, İstanbul: Kitabevi, 1996.

Kaplan, Mahmut. Divandan Seslenen Bilge Şair, Ankara: Öncü Kitap, 2009. 
Nâbî, şiir yoluyla toplumsal eleştiri anlamında dile getirdiği görüşlerinde mübtezel bir söyleyişe düşmemiş bilakis hüner ile hikmeti ve eleştiriyi şiir potasında birleştirme muvaffakıyetine ulaşmıştır. Ali Fuat Bilkan, "Nâbînnin Gazellerinde Görme Biçimleri” adlı makalesinde, bir şairin eşya ve olayları görme biçiminin ve imajları kullanma niteliğinin şairin üslubunu doğrudan belirleyen unsurlar olduğunu belirterek bu yönüyle Nâbînnin Divan şiirine getirdiği yeniliğe dikkat çeker. "Bu bakımdan, Divan şairlerinin ortak kelime dünyasına bakarak hepsinin de benzer şeyler söylediğini zannetmek yanlıştır. Zira Divan şiirinde önemli olan kullanılan malzeme değil, bu malzemenin kullanım biçimidir." (Bilkan 2006: 44).

Nâbînnin gazelleri arasında yer alan "bozundısıdır" redifli iki gazeli mevcut müşterek malzemenin kullanım biçimi vasfıyla şairin hünerini ve üslubunu ortaya koyması bakımından dikkat çekici özelliğe sahiptir. Nâbî, bu iki gazelinin her bir beytini kalb sanatı ile tezyin etmiştir. Bununla birlikte redif olan kelime ile kalb sanatı yapılan kelimeler ve beyitlerin anlamı arasında da lafız ve anlam bütünlüğü sağlanmıştır. Gazellerin bu yönüne geçilmeden önce kalb sanatı hakkında kısa bir bilgi verilecektir.

\section{Kalb Sanatı}

Bedî sanatlardandır. Kelime anlamı, “değişme”, "tersine dönme”, “altı üstüne gelme”dir. (Coşkun 2007: 243). “Bir kelimedeki harflerin yerlerini değiştirmek, fakat başka bir harf ilave etmemek şartiyle başka ve manalı bir kelime çıkarmaktır. Çıkarılan kelimeye "maklûb" denilir." (Tâhir-ül Mevlevi 1973: 83). "Cinasa bağlı lafiz sanatlarından sayıldiğı için cinâs-ı kalb, tecnis-i kalb veya maklûb adlarıyla anılır.” (Külekçi 1999: 231). Bu bakımdan Yekta Saraç, Klasik Edebiyat Bilgisi Belâgat adlı kitabında kalb sanatı için bir başlık açmamış bu sanatı cinas içinde göstermiştir.

“Cinası meydana getiren kelimelerdeki harflerin sıralanışının farklı olmasına cinâs-ı kalb adı verilir. Bu cinasta kelimeler aynı harflerden oluşur. Bu harfler sondan başa doğru sıralandığında başka bir kelime oluşturuyorlarsa bu tam bir kalb'dir (kalb-i kül); "felek" ile "kelef" kelimeleri gibi. Eğer harflerin sıralanmasında böyle bir sıra gözet(il)miyor ve diğer kelime sadece ayn harflerden oluşuyorsa bu eksik bir kalb'dir (kalb-i ba'z). "ihmâl" ile "imhâl" kelimelerinde olduğu gibi." (Saraç 2006: 247).

Kazvinî, kalb sanatını hem müstakil olarak hem de cinasın içinde inceler ve ona “tecnisü'l-kalb adını verir. (Kazvinî, Yanık vd, ty: 152, 158; akt. Coşkun 2007: 243). Sürurî, kalb yerine maklûb ifadesini kullanır ve onu maklûb-ı ba'z, maklûb-ı kül, maklûb-1 mücennah ve maklûb-ı müstevî olarak dörde ayırır. (Sürurî, Şafak 1991: 57-58).

“Kalb sanatının "akis"ten farkı kelimeye bağlı kalmasındadır. Akis ise cümlede olur." (Kocakaplan 2005: 89).

Kalb sanatı lafız ile ilgili olup hünere dayalı sanatlardandır. Nâbî, "bozundısıdur" redifli gazellerinin her beytinde bu sanata yer verir. Ancak Nâbî, kalb sanatının sadece 
$\underline{100 * \text { TAED }} 49$ ibrahim GÜLTEKIN

lafzî yönünden yararlanmaz; hüner gösterirken aynı zamanda redif olan kelimenin anlamından da yararlanarak gazellerde düşünce, hikmet ve toplumsal eleştiriyi ana tema olarak belirler. Çalışmanın bundan sonraki bölümünde Nâbînin her iki gazelinde bu durum beyitler üzerinde incelenerek değerlendirilecektir.

\section{Nâbĩ nin "bozundısıdur" Redifli Gazelleri ${ }^{3}$}

Gazel 148

Mefầilün Fe'ilâtün Mefầilün Fe'ilün

1 Gönülde dâg-ı mahabbet gıdâ bozındısıdur $O$ âh u vâh-ı ta'alluk hevâ bozındısıdur

2 Bulunsa tâzece ta'bîr-i nerm-sâze sezâ Lisân-ı köhnede âteş şitâ bozındısıdur

3 Fakîr mûre olur kayd-ı bâl 'ayn-i belâ Vedâ'ı nâf-ı zeminden fenâ bozındısıdur

44 'Aceb mi feth ile âsaf bulursa reng-i safâ Ki zâg-ı tîg-i şecâ'at gazâ bozındısıdur

5 'ibâdetinden ider ehl-i zühd ecr-i recâ Ki kârı bâr-keşânun kirâ bozındısıdur

6 Nüzûl-i ism semâdan delîldür buña kim O mâh-ı evc-i letâfet hümâ bozındısıdur

7 Nemâ nümûde-i emn oldugı dirahta sezâ Ki arz-ı perveriș itmek rızâ bozındısıdur

8 Ufuk kafâda nümâyân tekâbül üzre iken Zamâne yârı anunçün riyâ bozındısıdur

9 Egerçi Vân'dan olur Nâbiyâ nevâ ümmîd Velîk râh-ı hakîkat Ruhâ bozındısıdur

159. Gazel

Mefâ'ilün Fe'ilâtün Mefầilün Fe'ilün

1 Gönülde dâiye-i mâl emel bozundısıdur Nümûd-ı silk-i kanâ'at kesel bozındısıdur

2 Cihânı gerdiş ider haylîden bu köhne kıbâb Sipihre tesmiye-i Zâl ezel bozındısıdur

3 'Aceb mi mevt-i irâdîye düşse ehl-i sülûk Cilâ-yı âyine-i rûh ecel bozındısıdur

4 Rüsûm-ı âmed ü reft üzredür nizâm-ı cihân Siyâk-ı resm-i beled hep bedel bozındısıdur

${ }^{3}$ Gazeller, Ali Fuat Bilkan tarafından hazırlanan Nabi Divanı'ndan alınmıştır. BiLKAN, Ali Fuat. Nâbî Divanı l, Ankara: Akçă̆ Yayınları, 2011. 
5 Gören bilür şekerün gilden oldugun hâsıl Ki hulv-i sufre-i âlem vahal bozındısıdur

6 Cefâ-yı âleme sabr it safâ murâdun ise Ki les'-i hayye-i şöhret 'asel bozındısıdur

7 Ta'aafünâtını yâd eyle beyzâ vü ferhün Piliç lezîzdür ammâ çepel bozındısıdur

8 Kitâblarla medârisde bahs ider tullâb Kitâb cildi anuñçün cedel bozındısıdur

9 'Amel o kârgehün kemterîn kurâzasıdur Metâ'-ı 'ilme dinilmez 'amel bozındısıdur

10 Münâsebetledür evzâ'-ı tesmiye Nâbî Lügaz hele kati vâzıh gazel bozındısıdu

\section{Gazellerin Nesre Çevrilişi ve Açıklama ${ }^{4}$}

1 Gönülde dâg-ı mahabbet gıdâ bozındısıdur $O$ âh $u$ vâh-ı ta'alluk hevâ bozındısıdur

Nesir: “Gönülde aşk yarası gıda bozuntusudur (gıda sebebiyledir). (Dünya) ilgisinin o ah ile vahları (inleyip sızlanmaları) heves (istek, arzu) bozuntusudur (sebebiyledir)."

Nâbînnin "bozundısıdur" redifli her iki gazelinin en önemli tarafı beyitlerin her birinde şairin, kalb sanatına yer vermiş olmasıdır. Öyle ki beyitlerin anlam çerçevesini, kelimelerin birbirleriyle bağlantısını ve gazellerin omurgasını kalb sanatı oluşturur. Ayrıca şair, kalb sanatından hareketle bu iki şiirine özellikle "bozundısıdur" redifini seçmiştir. "Bir kelimedeki harflerin yerlerini değiştirmek, fakat başka bir harf ilave etmemek şartiyle başka ve manalı bir kelime çıkarmak" demek olan kalb sanatı ile "bozmak" fiilinden türemiş olan "bozındısıdur" redifi arasında da anlam yönünden ilişki söz konusudur. "Bozmak" ve "bozuntu" kelimelerinin sözlüklerde bazı anlamları şunlardır: "bozmak": Bir yerin, bir şeyin düzenini karıştırmak, biçimini ve kullanılışını değiştirmek.” “bozuntu”: 1 . Bozulmuş bir şeyin kalan bölümleri, döküntü. 2. Kendinde bulunması gereken nitelikleri taşımayan kimse veya şey. 3. Mec. Şaşkınlığa düşme.” (http://www.tdk.gov.tr, Erişim Tarihi 25.01.2013.) Böylece şair, kalb sanatı yoluyla bir kelimedeki harflerin yerlerini değiştirerek yeni bir kelime oluştururken bu sanatı, redif olan kelimenin kök hâli ve anlamı ile tamamlamaktadır.

${ }^{4}$ Çalışmada incelenen "bozındısıdur" redifli gazeller hakkında Ali Fuat Bilkan, "Hikmet-ŞairTarih" kitabında "Bozuntu Gazeli" adlı bir yazı kaleme almış ve yazısında Nâbînnin bu gazellerinin her bir beytinde yaptığı kalb sanatından hareketle "Divan şairlerinin tasannu yapmaktaki maharetlerini ve kullandıkları edebî dilin geniş hacmini" (Bilkan 1998: 201) dile getirmiştir. Bu çalışmada Ali Fuat Bilkan'ın mezkur makalesinden de istifade edilmiştir. Bununla birlikte kalb sanatının ve kullanılan redifin anlama katkısı da dikkate alınarak beyitler açıklanmış, Nâbînnin üslubunun belirgin özelliğini temsil eden hikmet, toplumsal eleștiri ile hünerin ne denli bütünleştiğinin tespiti yapılmaya gayret edilmiştir.

Bilkan, Ali Fuat. Nâbî Hikmet-Şair-Tarih, Ankara: Akçağ Yayınları, 1998. 
Nâbî, gazeline bir hiciv beyti ile başlar. Şairin hicvettiği, klasik şiir dünyasının merkezinde yer alan ve âşı̆̆a ait bir hâli ifade eden "aşk yarası"dır.

Nâbî, Hayriyé de çağdaşlarının nitelikli şiir yazamamalarını şu şekilde eleştirir.

Baksan ekser sühen-i şâir-i hâm / Zülf ü sünbül gül ü bülbül mey ü câm

Çıkmaz dâire-i dilberden / Kadd ü hadd ü leb ü çeşm-i terden

Geh bahara tolaşurgeh çemene / Ilişür serv ü gül ü yâsemene

Reh-i nâ-refte cevlân idemez / Sapa vâdîleri seyrân idemez

Idemez sayd-ı ma'ânî̀i bülend / Atamaz gayrı şikârına kemend

Geçinür ma'nî-i hâyîde ile / Lafz-ı meşhûr u cihân-dîde ile

(Kaplan 2008: 259)

Nâbî̀ye göre ham (olgunlaşmamış) şairin sözü zülf, sümbül, gül, bülbül, mey, câm vb. şiir geleneğin içinde yer alan müşterek unsurlarla doludur. Ayrıca Nâbîye göre ham şair, dilber dairesinden dışarı çıkamaz ve sadece dilberin kaddi, haddi, lebi ve çeşminden söz eder.

Şiirlerinde düşünmeye ve düşündürmeye ağırlık veren (ìsen 1997: 246) Nâbî için aşk yarasının müsebbibi gıda bozuntusudur. Ayrıca aşktan mütevellit gibi görünen ah u vahların asıl sebebi de heves ve arzu bozuntusundan başka bir şey değildir.

Nâbînnin, gazelin başlangıç beytiyle şiirlerinde daha çok aşk, aşk yarası, sevgili ve ona ulaşamamanın acısmı dile getiren şairlere göndermede bulunduğunu ve bu şairlerin yazdıklarını alaylı bir üslupla eleştirdiğini söyleyebiliriz.

Beyitte "dâg" ile "gıdâ", âh u" / "vâh" ile "hevâ" kelimeleri arasında kalb sanatı (kalbi ba’z) yapılmıştır. Kalb sanatının gerçekleştiği bu kelimeler arasında aynı zamanda şiirde dile getirilen düşünceye uygun bir anlam paralelliği söz konusudur.

\section{Beyti şu şekilde de yorumlayabiliriz.}

Âşığın gıdası sevgili ilgisizliği, cevr ü cefası ve hasretiyle sabah akşam yanı başından eksik olmayan gam ve kederdir. Ağlayıp sızlayıp inlemeleri de başında esen aşk havası nedeniyledir. Sevgili düşüncesiyle yemeden içmeden kesilen âşı, gece gündüz onu düşünmekten, acısını hafifletmek için dövünmekten bağrını yara bere içinde bırakmıştır. Beytin ilk mısrasında âşığın göğsünde göz açmış yaraların düzenli gıdasının bozulup yemeden içmeden kesilmesi, dövünüp bağrını başını yırtması sonucu olduğu söylenmek istenmiş. ikinci mısrada ise çekilen ah ve vâhların aşk sebebiyle olduğu ifade edilmiş. Gazelin genelinde redif konumunda olan "bozıntısıdur" sözüne her beyitte farklı bir anlam yüklenmiştir.

${ }^{5}$ Ali Fuat Bilkan, redif olan "bozundısıdur" kelimesinin tevriyeli kullanıldığını bu kelimenin şiirin bütününde aşağıdaki anlamları da çağrıştırdığını belirtir:

“parça, alamet, görüntü, bozukluk, kırıntı, bozulmuş, oluşmuş vb." (Bilkan 1998: 201-202). 
2 Bulunsa tâzece ta'bîr-i nerm-sâze sezâ Lisân-ı köhnede âteş şitâ bozındısıdur

Nesir: "Eski dilde ateş, kış bozuntusudur (Kış kelimesinin farklı bir biçimidir.). (Bu nedenle âteşe) uysal, yumuşak (ve) nazik yeni (tazece) terim bulunsa (ad konulsa) lâyıktır, yakışır."

Şâir, sadece göze hitap eden bir kalp sanatı yapmamış, sözüyle okuyucuyu da âteş kelimesi üzerinde düşünmeye sevk etmiştir. Âteş ile şitâ'nın harfleri eski yazıda eşit ve aynı harflerden oluşur. Şitâ eski yazıda tersten okunursa âteşe dönüşür. Bu nedenle, şair ısınma ve aydınlatmada kullanılan âteş ile soğuktan ortalı̆̆ kasıp kavuran ve bir hayli sert geçen kışın, aynı harflerle tanımlanmasını doğru bulmamış ve âteşe yeni, daha yumuşak bir ad konulması yolundaki temennisini dile getirmiştir. Ateşe daha yumuşak (nerm-sâz) bir ad konulmasının münasip olacağı önerisinde bulunmuştur.

Kalb sanatının yapıldığı kelimeler, birinci mısrada "sâz-sezâ" (kalb-i ba'z), ikinci mısrada "âteş-şitâ" (kalb-i kül).

3 Fakîr mûre olur kayd-ı bâl ayn-i belâ Vedâ'ı nâf-ı zeminden fenâ bozındısıdur

Nesir: “Mekke-i Mükerreme'den ayrılmak (veda) nasıl ki göçüp gitmeye işaret etmektedir fakir karıncanın da kanatlanması (onun için) musibetin ta kendisi olur."

Beyti şu şekilde de düşünebiliriz:

"Fakir karıncanın kanatlanması (nasıl ki onun için) musibetin ta kendisi olur, Mekkei Mükerreme'ye veda etmek de fani olmaya delalet eder."

"Nâf-ı zemin" zeminin, (dünyanın) ortası anlamına gelen bir tamlamadır. Beyitte Ekvatora yakın oluşu nedeniyle Mekke-i Mükerreme yerine kullanılmıştır. Sıcak iklimleri seven ve kâfile hâlindeki yolculuğu güneye doğru olan yoksul ve âciz karıncanın Kutsal topraklardan ayrılışının yok oluşa (fenâya) gidişinin işâreti olarak algılanması gerektiği îmâ edilmiştir. Bununla, yoksul ve âciz karıncanın kışın şiddetli soğuklarına dayanmasının güç olduğu, sıcak ve kutsal topraklardan ayrılışının yok oluşuna işaret ettiği söylenmek istenmiş.

Karıncalar, “iki temel yöntemle yeni koloniler kurarlar, kanatlı olanları uçarak uygun buldukları yerde kümelenirler ama en çok görülen yöntem dişi ve erkek karıncaların çiftleşme uçuşu yapmak için yuvayı terk etmeleridir. Normalde binlerce kanatlı kraliçenin çok azı hayatta kalır, çoğu kuşlar ve böcekler tarafindan yenirler, bazıları ise yeterince yumurtlamayı başaramadiğından açlıktan ölür.” (http://www.izafet.com/genelkultur/19646-karincalar.html, Erişim Tarihi 23.01.2013). “Karıncanın kanatlanması” zevalinin yakın olduğuna delalet eder." sözü halk arasında şayidir.” (Onay 2007: 230). Nâbî, beyitte bu inanışa gönderme yaparken aynı zamanda Hz. Peygamber'le ilgili bir başka 
tarihî olaya telmihte bulunur. Bilindiği üzere Hz. Peygamber 632 yılında son Hac farizası sırasında Müslümanlara seslenmiş, bu konuşmadan çok az zaman sonra vefat ettiği için tarihî konuşma Veda Hutbesi olarak adlandırılmıştır. Ayrıca Mekke'yi ziyaret eden Nâbî, Mekke'den ayrılışı kendisi içinde fani olmakla eş tutmuştur, diyebiliriz.

Karıncanın zevali "kanatlanmasından ileri geldiğine göre birinci mısrada kalb sanatı yapılan "bâl" ile "belâ" (kalb-i ba'z) kelimeleri arasında anlam ilişkisi dikkat çekicidir. "Bâl bela getirir." Beyitte karıncaların tatlı yiyecekleri sevmeleri de dikkate alınırsa "bal" kelimesinin bilinen anlamına da işaret olunduğu söylenebilir. Diğer kalb "ikinci mısradaki "nâf" ile "fenâ" (kalb-i ba'z) arasındadır.

4 'Aceb mi feth ile âsaf bulursa reng-i safâ

Ki zâg-ı tîg-i şecâ'at gazâ bozındısıdur

Nesir: "Yiğitlik kılıcının parlayışı (bileylenip parlatılması, keskinleştirilmesi) gazâ habercisi (olduğu için) Asaf, fetih ile safa rengi (safa) bulsa şaşılmaz."

Zag, kılıç ve bıçağa bilemekle verilen keskinlik, cila, kılağı manalarına gelen bir sözcüktür. Safvet kökünden türemiş olan safâ ise "saflık, arılık, temizlik, berraklık, parlaklık; gönül şenliği, kedersizlik, gamsızlık vb.” manalara karşılık düşen bir kelimedir. Beyitte kelimenin hemen bütün manalarına gönderme yapılmış. Bir önceki beyitte karıncadan (mûr) söz edildiği için (Süleyman a.s. ile Karınca kıssası) Asaf ile de Hz. Süleymân'ın veziri Âsafa atıfta bulunulmuş gözüküyor. Asaf sözcügü vezir anlamına da geldiği için genelde vezirin, özelde de $\mathrm{Hz}$. Süleymân'ın veziri Asafın kılıcının parlaklığının sefere işâret ettiği ve bu sefer sonucu gerçekleşecek fethin de gönlündeki kederi gidereceği için Asaf ın hem mutlu olmasına (safa bulmasına) hem de kederini giderdiği için gönlündeki mutluluğun yüzüne de yansıyarak gülümsemesine, yüzünün renginin değişmesine sebep olacağı ima edilmiştir.

Beyitte kalb sanatı birinci mısrada "âsaf-safâ" (kalb-i ba'z), ikinci mısrada "zâg- gazâ" (kalb-i ba'z) kelimeleri arasında yapılmıştır. “âsaf”ın safâ bulması ile "kılıcın bileylenmesi sonucu keskin hâle gelmesi anlamına gelen "zâg" ile "gazâ" arasındaki anlam ilişkisi aynı zamanda lafız sanatı olan kalb'in, hünerin ötesinde beytin anlamıla bütünleşmesine güzel bir örnek teşkil etmektedir.

5 'ibâdetin den ider ehl-i zühd ecr-i recâ Ki kârı bâr-keşânun kirâ bozındısıdur

Nesir: "Yük taşıyanların (çekenlerin) kazancını (bedenlerinin) kirası saymaları misâli zâhid kulluğundan sevap umar."

Beytin ilk mısrasında "ehl-i zühd" tamlaması ile zâhid, ikinci mısrada ise "bâr-keşân" ifâdesi ile hammâllar kasdedilmiş. ilk mısrada dindarlık gösterisinde bulunan zâhidin kulluğu / ibâdetini çıkarını düşünerek edâ ettiği, kulluğuna karşılık hep bir sevap kazanma ve günahlarından kurtulma umudunda olduğu beyan edilmiştir. Zâhid'in kulluğu 
sırtına ya da omuzlarına yüklenmiş bir yük gibi algıladığı ve karşılığında hep bir beklenti içerisinde olduğu belirtilmiştir. Onun kulluğuna karşllık Allah (c.c.)'tan sevap umudunda olması ile hammâl'ın taşıdığı yüke karşılık aldığı ücreti bedeninin kirâsı gibi algılaması arasında bir benzerlik kurulmuş. Bu benzetme ile dinî bir sorumluluk olarak Allah rızâsı için edâ edilmesi gereken kulluk görevini zâhid'in çıkar amaçlı olarak algıladığı ve bundan maddî - manevî kazanç elde etmeyi düşündüğü îmâ edilmiştir.

Klasik Türk şiirinde şairler, zahid ile âşık karşılaştırmasına sıklıkla yer vermişler ve âşığın beklentisiz aşk dileğine karşılık zahidin ibadet ve kullukta hep bir beklenti içinde olduğunu belirtmiş̧lerdir.

Şeyhîye ait aşağıdaki beyit, Nâbînnin beytinde yer verdiği düşüncenin bir başka biçimde ifade edilmesidir.

'Amelden ücret umunca gurûr-ı tâ'at ile

Günâhda muntazır-ı rahmet-i Hudâ olalım

(isen ve Kurnaz 1990: 221, G. 125)

Şeyhînin yukarıdaki beytiyle anlam bakımından aralarında benzerlik bulunan,

Zikri sôfinüñ sevâb u fikri Şeyhînüñ̃ günâh

Bâri mahrûm olmayısar ikimizden birümüz

(isen ve Kurnaz 1990: 177, G. 81)

şeklindeki beyti ile ilgili olarak sarfedilen "Zikri sôfinüñ sevâb ifadesinin zâhidin sevap kazanma düssüncesini ifade etmesinin aksine fikri Şeyhînnüñ günâh ifadesi de âşığın (Şeyhînnüñ) günah işleme ihtimâlini ve günahlarından ötürü Âllah'ın mağfiretine sığınma ve bağışlanma umudunu ima ediyor" (Zavotçu 2012: 403) cümlesi de zahid ve âşık karşılaştırması ile ilgili olarak yukarıda beyan ettiğimiz düşünceyi destekler mahiyettedir.

Kalb sanatının yapıldığı kelimeler, birinci mısrada "ecr-recâ" (kalb-i kül), ikinci mısrada "kâr-kirâ" (kalb-i ba'z). "Ecr" ile "recâ", "kâr" ile "kirâ" arasındaki dikkat çekici anlam ilişkisi aynı zamanda beytin bütününde verilen anlamla paralellik göstermektedir.

6 Nüzûl-i ism semâdan delîldür buña kim

O mâh-ı evc-i letâfet hümâ bozındısıdur

Nesir: "O güzellik zirvesi ayının hümâyı anımsatır olmasına ismin gökyüzünden inmesi delildir."

"Bozundısıdur" redifi beyitte "suretidir, kopyasıdır, nüshasıdır, benzeridir, nümûnesidir" gibi anlamlarda kullanılmış izlenimi vermektedir. ilk mısrada "nüzûl-i ism semâdan" ifadesiyle ismin gökyüzünden indiği söylenerek bununla cennetten yeryüzüne indirilen insanla birlikte ismin de yeryüzüne indiği belirtilmiş, denilebilir. Güzellik zirvesinin ayı olarak nitelenen sevgili ile hüma arasındaki benzerlik ise gerçekte var olmayan ve çok 
$\underline{106^{*} \text { TAED }} 49$

ibrahim GÜLTEKIN

yüksekten uçtuğu tasavvur edilen hümânın hayâlî bir kuş olması, bu nedenle yokluğu anımsatması nedeniyle olabilir. Güzellik zirvesinin ayı olan sevgili kusursuz güzeli, dolayısıyla ilâhî güzelliği çağrıştırır bir tamlama olmakla ulaşılmak istenen sevgilinin de yokluğu düşündüren ilâhî bir karakter arz ettiği söylenebilir.

Beyti, Nâbînnin eleştiri üslubunu dikkate alarak da yorumlayıp değerlendirmek mümkündür. Buna göre "letâfet zirvesinin ayı (sevgili), aslında Hüma bozuntusudur. Yani, Hüma kuşu nasıl ki ismi var cismi yok bir kuştur, klasik şiir dünyasının merkezinde yer alan "sevgili" de Hüma kuşu gibi adı var kendi yok bir güzellik burcudur. İsimlerin gökyüzünden inmesi de buna delil teşkil eder. Şairin, "mâh" ile "hümâ" kelimeleri arasında kalb yapması aynı zamanda bu yorumu teyit eder bir mahiyet göstermektedir.

Kalb sanatının yapıldığı kelimeler, birinci mısrada “ism-semâ” (kalb-i ba'z), ikinci mısrada "mâh-hümâ" (kalb-i ba'z).

7 Nemâ nümûde-i emn oldugı dırahta sezâ Ki arz-ı perveriş itmek rızâ bozındısıdur

Nesir: Çoğalmanın (artmanın, büyümenin, kazancın) rahatlık görüntüsü verdiği ăgaca layık (yaraşır) olduğu gibi beslenmeyi göstermek (besili görünüşs) de hoşnutluk belirtisidir.

Ağacın neması (kazancı, çoğalması) onun meyvelerini ifade eder. Ağaç için bu bir rahatlık görüntüsü, emniyetin belirtisidir. Meyvesi olan ağacın kendisini emniyette görmesi, korkusuz olması münasip düşer. Şair, meyveli ağaç örneğinden hareketle insan için de besili görünüşün (beslenmenin) hoşnutluk, memnuniyet belirtisi olduğunu söylüyor.

Birinci mısrada kalb olan kelimeler "nemâ" ile "emn”dir (kalb-i ba'z). Bu kelimelerin anlamına baktığımızda birbiriyle anlam ilişkisi içinde olduğunu görürüz. "Nemâ” (kazanç", "emn"e (rahatlık, korkusuzluk) zemin hazırlar. Kazancı olan adam rahat eder. ikinci mısrada da "arz" ile "rıza” kelimeleri arasında kalb sanatı yapılmıştır (kalb-i ba'z).

Beyit, şu şekilde de nesre çevrilebilir:

Nesir: Besili görünüş rahatlık belirtisi olduğundan büyümenin (dallanıp budaklanmanın) ağaca huzur vermesi münasiptir (uygundur, yakışık alır).

8 Ufuk kafâda nümâyân tekâbül üzre iken Zamâne yârı anunçün riyâ bozındısıdur

Nesir: Ufkun kafada görünen (göz erimi uzakliğa) karşılık düşmesi misâli zamanın sevgilisi bu sebepten ikiyüzlü karaktere sahiptir. 
ilk mısradaki "kafâda nümâyân" sözü ile gözün görebildiği en uç mesâfeler kasd edildiğinden bütün söylenip parça kasdedilmiş ve mecâz-1 mürsel sanatına başvurulmuş. Kafanın sağa ve sola yaklaşık 180 derecelik bir açı kadar döndürülebileceği düşünülürse gözün karşısına gelen geniş bir alanı tarayabileceği/gözetleyebileceği söylenmek istenmiş. Gözün sağa sola döndürülme nedeni ise ikinci mısrada îmâ yollu belirtilmiş. Zamane sevgililerinin gözlerini sürekli sağa sola çevirmelerinin ve farklı noktalara bakarak konuşmalarının sözüne güvenilmez, söylemi ile eylemi birbirini tutmayan ikiyüzlü kişiliklerinin işareti olduğu sezdirilmek istenmiştir.

Riya (ikiyüzlülük) münafiklık alametidir. Beyitteki "yâr" kelimesinin "dost", "ahbap" anlamını dikkate aldığımızda Nâbînin yaşadığı dönemde genel anlamda dostluk ilişkilerinin bozulmuş olmasına dikkat çektiği söylenebilir.

Ali Fuat Bilkan (1998: 204) bu beyti şu şekilde günümüz Türkçesine aktarır:

"Ufuk (kelimesi), kafa kelimesini karşıladığı gibi, zamane yâri, sevgilisi de bu şekilde riya bozuntusudur."

Kalb sanatının yapıldığı kelimeler, birinci mısrada "ufuk-kafa" (kalb-i ba'z), ikinci mısrada "yâr-riyâ" (kalb-i ba'z). Kalb yapılan kelimeler arasındaki anlam ilişkisi aynı zamanda beytin anlamı ile de paralellik göstermektedir.

9 Egerçi Vân'dan olur Nâbiyâ nevâ ümmîd Velîk râh-ı hakîkat Ruhâ bozındısıdur

Nesir: "Ey Nabi, refâh (nasib) (her ne kadar) Van'dan umulur ama, hakîkât yolu Ruhâ'dan geçer (Ruhâ'da izini gösterir)."

Ali Fuat Bilkan (1998: 204) beyti şu şekilde günümüz Türkçesine aktarmıştır:

"Ey Nâbî, gerçi nevâ (makamı)nın Van'dan (veya van kelimesinden) meydana gelmesi beklenir, ancak gerçekte Ruhâ (veya Urfa'nın eski adı Ruhâ)nın bozuntusudur, Ruhâ'ya aittir.

İskender Pala'da (2010: 32) aynı beytin nesir hâli aşağıdadır:

“Ey Nâbî! Gerçi Van'dan müjdeli bir haber, bir refah umudu taşıyorsun ama gerçeklerin akışı seni Urfa'da yaşadı̆ı̆ı kırık dökük hayata mahkûm etmiş."

Mine Mengi de (2012: 47) "Nâbînin Şiirlerinde Urfa, İstanbul, Halep" adlı makalesinde aynı beyti şu şekilde nesre çevirmiştir:

“Ey Nâbî, sesin âhenklisi Van'dan (Vanlı olan Şair Nefi'den) beklenir; ama gerçeğin, doğrunun yolunu da Urfa bozuntusu olan (Urfa doğumlu Nâbî) bilir."

Mine Mengi (2012: 53) bu beyitle ilgili olarak ayrıca şu açıklamayı yapar: 
"Söz konusu gazelinin son beytinde Nabi, kendisinden önce 16. yy.ın ikinci yarısı ile 17. yy.ın ilk yarısında (1572-1635) yaşamış olan ünlü şair Nefi'ye gönderme yapmakta ve onun şiirlerinin ahenkli olarak tanınıp bilindiğine işaret etmekte; kendisiyle Nefi'yi karşılaştırmakta; Urfalı olan kendisinin (Nefi'den farklı olarak) şiirde anlamdan, düşünceden yana olduğuna dolaylı olarak değinmektedir. Bizce, beyitte geçen Ruha bozuntusu ise herhalde; Urfa'da uzun süre kalmadığı için Urfalı özelliklerini tam taşımadığını ima etmektedir!”

Eski adı Ruha olan Urfa şehri Şair Nâbînin, "doğduğu, çocukluğunu ve ilk gençlik yıllarını geçirdiği, ilk eğitimini aldı̆̆ı, şïre ilk merak sardı̆̆ı yerdir.” (Mengi 2012: 46). Nâbî, bir başka beytinde Urfa'ya olan özlemini dile getirir:

Nâbî gazeli gibi hoş-âyendeliğin var

Ey bâd-ı revân-bahş Ruhâdan mı gelirsin

(Bilkan 2012: G. 654)

"Ey cana can katan rüzgâr; Nâbînnin gazelleri gibi hoşsun, güzelsin. Yoksa sen Urfa'dan mı gelirsin? Urfa'dan geldiğin için mi böyle rahatlatıcı, böyle hoşsun?” (Mengi 2012: 46).

Urfa, aynı zamanda mukaddes bir mekândır. “Urfa; Ceddü'l-enbiyâ yani ibrahim Peygamber'in doğup büyüdüğ̈̈, orada putları kırdığı, bu nedenle de Hükümdar Nemrud'un emriyle ateşe atıldığı ancak ateşin yerinde güllerin bittiği şehirdir.” (Mengi 2012: 47). Van ile Urfa'yı karşılaştırdığı beytinde Nâbî için Urfa "râh-ı hakikat"tir. Bu kelime öbeğine Hz. ibrahim'den mülhem dinî bir anlam verilebileceği gibi Nâbînnin sanattaki kudretine yakışır şekilde Mine Mengi'nin yorumu ile de açıklanabilir.

Kalb sanatının yapıldı̆̆ı kelimeler, birinci mısrada "Van-nevâ" (kalb-i ba'z), ikinci mısrada "râh-Rûha" (kalb-i ba'z).

\section{Gazel}

1 Gönülde dâiye-i mâl emel bozundısıdur Nümûd-ı silk-i kanâ'at kesel bozındısıdur

Nesir:Gönülde mal (edinme) hırsı emel bozukluğundandır (sebebiyledir). Kanaat yolunun göstergesi tembellik bozukluğundandır (bozukluğudur).

Divan şiirinde geçici, dünyevî istekleri anlatmak için "hevâ", "heves" ve "ârzû" sözcükleri sıkça zikredilir. "Emel", "taleb" ve "murâd" sözcükleri ise divan şiirinde genellikle gelip geçici değil uzak ve ebedî isteği, amacı ve nihâî hedefi anlatırlar. ilâhî aşkın işlendiği tasavvufî dîvân şiirinde Mutlak sevgiliye ulaşma talebinde olan, Allah (c.c.)'ın varlığında önce yok olup akabinde ebedî var olmayı amaç edinen âşığın tembellikle işi olmaz. ikinci mısrada bu husus anlatılmak istenmiştir. ilk mısrada ise tam tersi bir durum söz konusudur. Bu mısrada, gönlünde mal ve mülk edinme isteği olan kişinin emelinin bozuk olduğu, dünyevî istek ve arzuların peşine düşüp Mutlak güzelliği ve manevî zenginliği unuttuğu îma edilmiştir. 
Beytin ilk mısrasında geçen "emel” ve "mâl” sözcüklerinin eski yazıda harfleri aynı olup yerleri değişiktir. Aynı beyitte kullanıldıkları için aralarında kalb sanatı vardır. Emel'in ilk harfi olan Elifin yeri değiştirilir ve ikinci sıraya konursa emel mâl'a dönüşür. Böylece, Mutlak Güzelliğe ve ilâhî Sevgili'ye ulaşma emelinde olması gereken kişi asıl olandan yüz çevirip geçici güzelliklerin ve dünyevî isteklerin peşine düşmüş, mal-mülk edinme heveslisi olmuş sayılır. Mısraya bu açıdan bakıldığında şâirin emel ve mâl sözcükleri arasındaki kalb sanatını mana ile de başarılı bir biçimde ilişkilendirdiği söylenebilir.

Nâbînnin bu beyitte özellikle ikinci mısrada tarikat ehline de eleştirel bir gönderme yaptığı görülmektedir (Deger 2012: 85-86). Tasavvufi düşünce sisteminde dünya malı ve ziyneti kişi için hakiki aşk yolunda bir engel olarak görülür. Dolayısıyla "Bir lokma bir hırka" anlayışı olgunlaşma sürecini gerçekleştirme yolunda mürid için anlamlı bir yere sahiptir. Ancak bu anlayış zaman içinde tarikatların de bozulmasıyla yerini uyuşukluğa ve tembelliğe bırakmıştır. 17. yüzyıl tarikatlarda da ferdî ve kurumsal bozulmanın yaşandığı bir döneme tekabül eder. Nitekim bu durumu gözlemleyen Nâbî, "bozundısıdur" redifli ikinci gazelinin başlangıç bölümünde eleştiri oklarını bu vakıaya yöneltir.

Kalb sanatının yapıldığı kelimeler, birinci mısrada "mal - emel” (kalb-i ba'z), ikinci mısrada "silk- kesel" (kalb-i ba'z). "Silk" “yol” demektir, "kesel” de "tembellik" anlamına gelir. Bu kelimeler arasında da beytin muhtevasına uygun bir anlam ilişkisi söz konusudur. Bu iki kelime okuru "Yolda tembellik olmaz." ya da "Tembellik yapan yolda kalır." ana fikrine ulaştırır.

2 Cihânı gerdiş ider haylîden bu köhne kıbâb Sipihre tesmiye-i Zâl ezel bozındısıdur

Nesir: Bu eski (yaşhı) kubbeler çok zamandır dünyayı dönüp devr ederler. Gökyüzüne (feleğe) Zâl adı verilmesi Ezel'den bozmadır.

Dîvân Şiirinde Gökyüzü (felek) dokuz ya da yedi kat olarak tanımlanır ve göğün her bir tabakasında bir gezegenin bulunduğu varsayılır. Eski inanışa göre yaratılmış her şey, canlı-cansız bütün varlıklar yaratıldıkları günden beri "Hu, Hu” çekerek Allah aşkıyla dönerler. Gök kubbe de yaratıldığı zamandan, Ezel'den beri Allah aşkıyla dönmektedir. Tazarru'-nâme'de geçen “Aşk iledür gögün döndügi. Aşk iledür yerin turduğu. (...) Aşkdur yıldızları seyr itdüren. Aşkdur ay u güni devr itdüren.”(BTK C 2, 2004: 273) cümleleri de bu dönüşün aşk ile olduğunu beyan etmektedir.

Beytin ilk mısrasında geçen "ezel" ve "Zâl” sözcüklerinin eski yazıda harfleri aynı olup yerleri değişiktir. Aynı beyitte kullanıldıkları için aralarında kalb sanatı vardır. Ezel'in ilk harfi olan Elifin yeri değiştirilir ve ikinci sıraya konursa "ezel" "Zâl"'e dönüşür. Ezel "Başlangıcı olmayan geçmiş zaman, öncesizlik...” (Devellioğlu 2008: 245) olup Allah'ın ruhları huzurunda toplayıp onlara "Elestü bi-Rabbiküm (Ben sizin Rabbiniz 
değil miyim?)" sorusunu yöneltip ruhlardan “belâ" (evet) cevabını aldığı meclisi (Elest Meclisi, Meclis-i Elest, Bezm-i Elest) anımsatır. (Devellioğlu 2008: 214). Zâl de "ı. Ihtiyar, aksakallı, zâlim, acımasız. 2. (h.i.): eski Fars kahramanlarından meşhur pehlivan Rüstem'in babasının adı" (Devellioğlu 2008: 1166) manalarına gelen Farsça bir sözcüktür. Aralarında kalb sanatı olan bu iki sözcügün manaları arasında da bir ilişki kurulabilir. Çok eski zamanlarda (hayliden), ezelde yaratılmış olan gök kubbe eski ve yaşlı olarak nitelenir. îhtiyâr, ak sakallı manalarına gelen Zâl de yaşlı demektir. Dolayısıyla eski yazıda harfleri aynı yazılışları farklı olan bu iki sözcük arasında manaca da benzerlik ve yakınlık vardır.

Kalb sanatının yapıldığı kelimeler, ikinci mısrada “Zâl-ezel” (kalb-i ba’z).

3 'Aceb mi mevt-i irâdîye düşse ehl-i sülûk Cilâ-yı âyine-i rûh ecel bozındısıdur

Nesir: Sâlik kendi isteğiyle ölüme gitse şaşılmaz. Rûh aynasının parlaklı̆̆ı (cilası) ecelden bozmadir.

Beyitte nefis terbiyesi, gönlün dünyevî arzûlardan arındırılması hususu işlenmiştir. Tasavvufî şiirde dünya, fânîdir ve sonu olduğu için dünyevi güzellik ve zenginliklere bağlanmak ebedî mutluluğa eriştirmeyecek isteklerin peşinden koşmaktır. Asıl olan ebedî varlık ve ebedî mutluluktur. Sâlik bu mutluluğa nefis terbiyesi ve aşk ile erişebilir.

Ölüm iki çeşittir. ilki tabîi ölüm olarak adlandırılır ki bedenin ölmesi demektir. Yûnus Emre'nin deyimiyle “Ölürse tenler ölür cânlar ölesi değil”. Bu ölümde cân, yani gögüs kafesinde hapis hayatı yaşayan rûh esâretten kurtularak asıl vatanına, ait olduğu yere döner. îkinci tür ölüm ise nefis terbiyesi de denilen irâdî ölümdür. "Nefsin heva ve hevesinin kökünü kazımak. Nefsin canı bu hevâ ve hevestir. Onu maddî hazlara ve bedenî zevklere yönelten heva ve hevesin yok edilmesi nefsin ölümü anlamına gelir. Ölmeden evvel ölmek" budur. Nefis suflî âleme çekilince kalb ölür. Ulvî âleme çekilince kalb ve rûh hayat bulur. Nefsi öldürmek için açılan savaşa cihad-ı ekber denir. (Kâşânî)" (Uludağ 1995: 363, 364)

"Mûtû kalbe en-temûtû: Ölmeden önce ölünüz" (Yılmaz 1992: 128) sözünün manası gereğince sâlikin dünyevî istek ve zenginliklere değer vermemesi kendisini ebedî hayat ve mutluluğa götürecek aşk olgusunun temelidir. Buna da şaşılmaması lazım gelir, olması gereken bir durumdur. Rûh aynasının (cilâsı) parlaklığı ecelden bozmadır manasındaki ikinci mısra da ilk mısra ile aynı manadadır. "Nefis suflî âleme çekilince kalb ölür. Ulvî âleme çekilince kalb ve rûh hayat bulur." cümlelerinde belirtildiği üzere nefsi öldürmek rûha dirilik ve hayat (cilâ, parlaklık) verir. Bu bağlamda, ilk mısradaki mevt-i irâdî tamlamasının manasında zıtlık (tezâd) bulunduğu söylenebilir.

ikinci mısradaki "parlatma, parlaklık" (mecâzen hayat, dirilik) (Devellioğlu 2008: 142) manalarındaki cilâ ile ölümü ve ölüm zamanını anlatan ecel sözcükleri, eski yazıda harf sıraları olup aynı harflerle yazılan iki sözcüktür. Bu nedenle aralarında kalb sanatı 
vardır (kalb-i ba'z). Aralarında kalb ilişkisi olan bu kelimeler beytin genel anlamı çerçevesinde de birbirini tamamlayıcı nitelik göstermektedir.

4 Rüsûm-ı âmed ü reft üzredür nizâm-ı cihân Siyâk-ı resm-i beled hep bedel bozındısıdur

Nesir: Cihanın düzeni, gidiş ve geliş usullerine göredir. Şehir planının ifadesi hep karşıllğının bozuntusudur (şehir planını düzenlemek karşılığında bir şsey ya da yerleri bozmayı gerektirir).

Beyitte iyi ve güzel şeyler yapmak istemenin karşıllğında bir şeyleri bozmayı, bir yerleri yıkmayı gerektirdiği söylenmek istenmiştir. ilk mısrada dünyanın düzeninin bir gidiş-geliş üzere olduğu belirtilmiş. Bununla hem sürekli bir doğum ve ölüm hadisesi yaşandığı (birileri doğarken birileri de ölür) hem de bir şeyler yapılırken bir şeyler de bozulur ya da yıkılır denmek istenmiş. ikinci mısrada ise eski yazıda aynı harflerle yazılan, fakat harf sıraları farklı olduğu için aralarında kalb sanatı bulunan "beled" ve "bedel" sözcüklerinden beledin bedelden bozma olduğu ifade edilmiş. Beyitte her iyi şeyin, şehrin düzenli oluşunun bile bir bedeli olduğuna çağrışımda bulunulmuştur.

Kalb sanatının yapıldığı kelimeler, ikinci mısrada "beled-bedel" (kalb-i ba’z).

5 Gören bilür şekerün gilden oldugiun hâsıl

Ki hulv-i sufre-i âlem vahal bozındısıdur

Nesir: Âlem sofrasının helvası (tatlısı) çamur bozuntusu olduğu (çamuru anımsattığı) için gören, şekerin topraktan meydana geldiğini bilir.

Beyitte sûrete değil sîrete, görünüşe değil öze ve niyete bakmak gerektiği îmâ edilmiştir. Toprak hayat için gerekli olan dört temel unsurdan adi ve değersiz bir madde olmasına rağmen insanın hamuruna temel olmuştur. Ayrıca, insan ve hayvanlara rızk olan birçok bitki, meyve ve sebzenin bitmesine de yatak ve temel olmuştur. Dolayısıyla, kendisi değersiz bir varlık sayılsa da hayat için gerekli pek çok şeyin kaynağıdır.

Beytin ilk mısrasında toprağın tat veren şekerin yetişmesine kaynak olduğu söylenmiş, ikinci mısrada ise şekerin toprakta yetişmesi sofradaki helvanın çamuru anımsatması ile desteklenmiştir. Mısrada geçen "hulv" ve "vahal" sözcükleri eski yazıda aynı harflerle yazılırlar. Böyle olmakla birlikte, her iki kelimede harflerin sırası değişik olduğu için aralarında kalb sanatı vardır (kalb-i ba'z).

6 Cefâ-yı âleme sabr it safâ murâdun ise Ki les'-i hayye-i şöhret 'asel bozındısıdur

Nesir: "Şöhret yılanının zehiri balı anımsattığı için murâdın safầ ise dünyanın cefâsına katlan." 
Beytin ikinci mısrasında geçen Arapça les‘ sözcüğü yılan ve akrep sokması manasına gelse de beyitte zehir manasında kullanılmış. Beytin genelinde varlıkların zıddıyla kâim olduğu, biçim ve içerik bakımından aralarında zıtlık bulunan varlıkların bile birbirlerine gereksinim duyduğu îma edilmiştir. Bu duruma örnek olarak da zehir manasındaki les' ile bal manasındaki asel'in aslında aynı şey oldukları ileri sürülmüş. Tezat ilişkisi içinde verilen bu kelimeler "les'-'asel” (kalb-i ba'z), aynı zamanda şairin beyitte işlediği düşünceye uygunluk gösterir. Nâbî, beytin anlamını zıtlık ilişkisi içinde bulunan kelimeleri bir arada kullanarak destelemiştir. Birinci mısrada da "cefâ-safâ" kelimeleri arasında tezat ilişkisi söz konusudur.

$7 \quad$ Ta'affünâtını yâd eyle beyzâ vü ferhün

Piliç lezîzdür ammâ çepel bozındısıdur

Nesir: Yumurta ve civcivin kötü kokularını hatırla, piliç lezzetlidir ama pislik ve bataklık bozuntusudur (pislikte yetişmiştir).

Şair beyitte düşüncesini tümevarım yöntemiyle dile getirmiştir. ilk mısrada yumurta ve civcivin kötü kokusuna atıfta bulunmuştur. Yumurta, belirli bir zaman diliminde tüketilmezse bozulur ve çok kötü bir koku yayar. Kuluçka için konulan döllenmiş yumurta da içinden civciv çıkınca kötü kokar. ilk mısrada yumurta ve civcivin kötü kokusu hatırlatan şair bu kokuyu ikinci mısrada zikrettiği pislik ve bataklık ile ilişkilendirmiş. Çepel (çipil): “1. Kirli, pis, mundar. 2. Pislik. 3. Bataklık” (YTS 1983: 53) manalarına gelen bir sözcüktür. Pilicin bataklık ve çöplükte eşelenip yiyecek araması ve bulduğu yiyeceği yemesini ifade için bu sözcük zikredilmiş ve beyite yerleştirilmiştir. Şair bununla, daha embriyo aşamasında iken yumurta içinde kötü kokuya alışan civcivin, büyüme sürecinde de pislikle haşır neşir olduğunu, eti lezzetli olmasına rağmen yiyeceğinin bir kısmını çöplük ve bataklıktan temin ettiğini söylemek istemiştir. Aynı zamanda, canlıların sindirim sisteminin mükemmel bir arıtma cihazı olduğunu ve gıdaların pis kısmını atıp yararlı kısmını ete dönüştürdüğünü de îmâ etmiştir.

ikinci mısrada geçen piliç ve çepel (çipil) sözcükleri eski yazıda aynı harflerle yazılırlar. Böyle olmakla birlikte, her iki kelimede harflerin sırası değişik olduğu için aralarında kalb sanatı vardır (kalb-i ba'z).

$8 \quad$ Kitâblarla medârisde bahs ider tullâb Kitâb cildi anuñ-çün cedel bozındısıdur

Nesir: Talebe (ögrenciler) medreselerde kitaplarla (kitabî bilgiler yardımıyla) konuşur. Kitap cildi bu nedenle kavga ve tartışma bozuntusudur (mağdurudur).

Beytin ilk mısraında medreselerde eğitim gören talebenin (öğrencilerin) kitaplardan edindiği bilgiler yardımıyla konuştuğu, farklı konularda fikir beyanını kitâbî bilgiler yardımıyla yaptığı söylenmek istenmiş. íkinci mısrada ise talebenin bilgi edinmek için sık sık kitaba müracaat etmesi, kapağını açıp sayfalarını karıştırması sebebiyle kitap cildinin 
yıpranıp yırtıldı̆ı, kavgadan (cedelden) çıkmış gibi perişan bir görüntüye sahip olduğu îmâ edilmiştir.

Beyitte medrese ehline eleştirel gönderme yapıldı̆̆ını söylemek de mümkündür. Medrese ehlinin boş tartışmalar ile zamanını geçirdiği ifade edilirken bu durum, onların yazdıkları kitapların bir hâli ile (ciltlerin dağınıklı̆̆ı) örneklendirilerek dile getirilmektedir.

ikinci mısrada geçen cild "I.Deri, Kap, Kitap, Meşin. (ten. 2. Formaları, yaprakları birbirine dikerek veya yapıştırarak, defter, dergi, vb.ne geçirilen deri, bez veya kâğttla kaplı kapak. 2. Bir eserin ayrı ayrı basılan bölümlerinden her biri." (http://www.tdk.gov.tr, Erişim Tarihi 25.01.2013), cedel ise "I. Sert münakaşa, tartışma. 2. kavga" (Devellioğlu 2008: 128) manalarına gelen ve eski yazıda aynı harflerle yazılan iki sözcüktür. Aynı harflerle yazılmalarına rağmen harflerinin sırası değişik olduğu için aralarında kalb sanatı vardır (kalb-i ba'z).

9 'Amel o kârgehün kem-terîn kurâzasıdur Metâ'- - 'ilme dinilmez 'amel bozındısıdur

Nesir: ilim sermayesine iş bozuntusu denil(e)mez. (Çünkü) iş, o iş yerinin en değersiz döküntüsüdür.

Beyitte bilimin değeri ve önemi vurgulanmış. Felsefí şiirin önemli bir temsilcisi olan Nâbî, bilimin önemine inanan ve hayatını bilimle renklendiren bir şair ve düşünür olduğu için beyti ilimle amel etme düşüncesi üzerine kurmuş. Bu yüzden, ikinci mısrada ilmi metâ (sermaye, geçimlik ve kazanç) olarak nitelemiş ve ilmi hem kazanç ve geçimlik, hem de alınıp satılan bir eşya olarak görmüş. Bu nitelemeyle, bilgi edinen kişinin bilgisini saklamaması, eğitim, öğretim ve aydınlatma faaliyetinde bulunması ve bildikleriyle mezara gitmemesi îmâsında bulunmuştur.

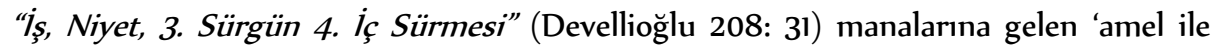
"I. Bilme, biliş̧; bir şeyin doğrusunu bilme. (...). 2. Okuyarak öğrenilen bilgi, nazarî bilgi" (Devellioğlu 208: 429) manalarındaki 'ilm sözcükleri eski yazıda aynı harflerle yazılırlar. Aynı harflerle yazılmalarına rağmen harflerinin sırası değişik olduğu için aralarında kalb sanatı (kalb-i ba'z) vardır. Şairin, kalb sanatını ilim kelimesi ile amel kelimesi arasında yapması boşuna değildir. Bu kelimeler arasındaki kalb ilişkisi ilmiyle amel etmek hususundaki birçok göndermeye açıktır.

Io Münâsebetledür evzâ'-ı tesmiye Nâbîlügaz hele kati vazıh gazel bozındısıdur

Nesir: Ey Nabi, isimlendirme (isim koyma) hâlleri bir münasebet iledir. (Bir ilgi, alaka iledir). Lügaz (bilmece) hele çok açı lügaz, gazel bozuntusudur.

Bilkan (1998: 200), Nâbî̀nin, tasannu yapmadaki maharetini şu şekilde açılar: "Nâbî, Divan'inda kelime oyunlarına dayanan sanatlara çok fazla yer vermiştir. Şairin, 
mu’amma ve lügaz türündeki başarısı bu sahadaki ustalĭğ, aynı üslubun gazel nazım şekliyle yazılmışs şiirlere de yansımasına yol açmışstır." Belagate dâhil edilen hünerlerden lügaz, "insan isminin dışında, bir șeyin özelliklerinin söylendiği ve muhataptan bunun ne olduğunun sorulduğu bir tür bilmecedir." (Saraç 2006: 292). Lügaz ya da muamma gibi hünere dayalı sanatlarla şiir söyleme klasik Türk edebiyatı şairi için önemli bir belagat kabiliyetidir. Bu sahadaki başarısını ve hünerini tescil etmiş bulunan Nâbî, gazelin son beytinde eleştiri okların Divan şairine yöneltir. "Bu beyitte Nâbî, söyledikleri lügazları açı bir şekilde anlaşılan şairlerin şiirlerini gazel bozuntusu olarak nitelendirmiştir." (Deger 2012: 87). Ayrıca şiirde yapılan bilmece anlamına gelen lügazın gazel kelimesinden oluştuğunu ifade ederek mezkur mısrada bir lügaz sanatı da yapmış olur. Şair, gazelini hüner içinde hüner gösterisi ile tamamlar.

Kalb sanatının yapıldığı kelimeler, ikinci mısrada "lügaz-gazel” (kalb-i ba’z).

\section{Sonuç}

Nâbî̀nin Divan'ında "bozındısıdur" redifli iki gazel bulunmaktadır. Birinci gazel (Divan'da 148. gazel) dokuz beyit, ikinci gazel (Divan'da 159. gazel) on beyittir. Bu gazelleri önemli kılan belirgin husus gazellerin merkezinde kalb sanatının yer almasıdır. 148. gazelde beyitlerin her mısrasında, 159. gazelin birinci beytinin her iki mısrasında diğer beyitlerin ikinci mısralarında kalb sanatı yapılmıştır. Buna göre dokuz beyitlik 148. gazelde toplam on sekiz kalb sanatı varken 159. gazelde on bir kalb sanatına yer verilmiştir. Her iki gazelde kalb sanatı sayısı toplam yirmi dokuzdur.

Nâbî̉nin, gazeller için redif olarak belirlediği kelimenin bilinçli bir tercihe bağlı olduğu sezilmektedir. "Bozundısıdur" kelimesinin kökeni "bozmak" fiilinden gelir. Kalb sanatında da beyitte ya da mısrada kullanılan bir kelimenin harflerinin yerleri değiştirilerek/bozularak anlamlı yeni bir kelime türetmek ve bu kelimeyi önceki ile aynı mısra/beyit içinde kullanmak söz konusudur. Bu da gösteriyor ki Nâbî, hünerini sadece kalb sanatı üzerine inşa etmemiş ayrıca şiirin merkez noktasını teşkil eden redifi de bu hünerine dâhil etmiştir.

Bozulmaya yüz tutan bir dönemde yaşamış olan Nâbî, şiir zekâsı ile aydın sorumluluğunu şiir potasında birleştirmiş bir şairdir. Onun şiir dünyasının ana gövdesini hikmet, düşünce ve toplumsal eleştiri oluşturur. "Bozmak" fiilinden türeyen "bozındi/bozuntu" kelimesini/redifini birçok manaya gelecek şekilde kullanan şair, kelimenin olumsuz anlam tedailerinden de yararlanarak gazellerinde daha çok hikmet, düşünce ve toplumsal eleştiriye yer vermiştir.

Sonuç olarak Nâbînnin bu iki gazeli onun üslubunun üç yönünü temsil eder. Birincisi hünere dayalı sanatları kullanmadaki mahareti ve beyitlerde bu sanatlara uygun kelime seçimindeki ustalığı. İkincisi hikemî üslubu. Üçüncüsü de hüner ile hakimane üslubun birleşiminden doğan belagat gücü. Bununla birlikte gazellerin genel yapısı ve içeriği Nâbînnin hünere dair sanatları daha doğrusu şiir sanatını, hikemî söyleyiş için birer vasıta kıldığını da göstermektedir. 
Nâbînnin üslubuna dair özelliklerinin bir yönünü zevk-i selim/meleke teşkil etmekle birlikte yaşadığı dönemin onun üzerinde bıraktığı çok yönlü tesirin de katkısını belirtmek gerekecektir.

\section{KAYNAKÇA}

BiLKAN, Ali Fuat. Nâbî Hikmet-Şair-Tarih, Ankara: Akçağ Yayınları, 1998.

BilLKAN, Ali Fuat. "Nâbînnin Gazellerinde Görme Biçimleri", Osmanlı Şiiri'ne Modern Yaklaşımlar, s. 43-56, istanbul: L\&M, istanbul 2006.

BilKKAN, Ali Fuat. Nâbî Hayatı Sanatı Eserleri, Ankara: Akçağ Yayınları, 2010.

BiLKAN, Ali Fuat. Nâbî Divanı 1-1l, Ankara: Akçağ Yayınları, 2011.

Büyük Türk Klasikleri; Ötüken Yay., C 2, İstanbul 2004.

COŞKUN, Menderes. Sözün Büyüsü Edebî Sanatlar, İstanbul: dergâh yayınları, 2007.

DEGER, Mete Bülend, "Nâbînnin Türkçe Divanı'nda Hiciv", The Journal of Academic Social Science Studies JASS, Volume 5 lssue 1, p. 75-96, February 2012.

DEVELLiOĞLU, Ferit. Osmanlıca-Türkçe Ansiklopedik Lûgat, 25. Baskı, Ankara: Aydın Kitabevi, 2008.

http://www.izafet.com/genel-kultur/19646-karincalar.html, Erişim Tarihi 23.01.2013.

http://www.tdk.gov.tr, Erişim Tarihi 25.01.2013.

iPEKTEN, Haluk. Nâilî Divanı, Ankara: Akçă̆ Yayınları, 1990.

iSEN, Mustafa, Cemal KURNAZ. Şeyhî Divanı, Ankara: Akçağ Yayınları, 1990.

iSEN, Mustafa. "Divan Edebiyatında Geleneğe Direnenler l Nâbî", Ötelerden Bir Ses, s. 244-250, Ankara: Akçă̆ Yayınları, 1997.

KAPLAN, Mahmut. Hayriyye-i Nâbî, Ankara: Atatürk Kültür Merkezi, 2008.

KARAHAN, Abdülkadir. Nâbî, Ankara: Kültür ve Turizm Bakanlı̆̆ı Yayını, 1987.

KARAHAN, Abdülkadir "Nâbînnin Sanatı ve Şahsiyeti”," Şair Nâbî, s. 85-109, (Editör Ali Fuat Bilkan), Ankara: Kültür Bakanlığı, 2012.

KOCAKAPLAN, ìsa. Açıklamalı Edebî Sanatlar, ìstanbul: Türk Edebiyatı Vakfı Yayınları, 2005.

KORTANTAMER, Tunca. "Nâbînnin Osmanlı Imparatorluğunu Eleştirisi", Tarih İncelemeleri Dergisi 11, İzmir, 1984, s. 83-116, Şair Nâbî, (Editör Ali Fuat Bilkan), s. 109-143, Ankara: T.C. Kültür ve Turizm Bakanlığı, (2012).

KURNAZ, Cemal. "Nâbî̀de Belge-sel Redifler”, s.63-68, (Editör Ali Bakkal), Şanlıurfa: Şair Nâbî Sempozyumu 13-15 Kasım 2009.

KÜLEKÇi, Numan. Açılamalar ve Örneklerle Edebî Sanatlar, Ankara: Akçağ Yayınları, 1999.

MENGi, Mine. Divan Şiirinde Hikemî Tarzın Büyük Temsilcisi Nâbî, 2. Baskı, Ankara: Atatürk Kültür, Dil ve Tarih Yüksek Kurumu Atatürk Kültür Merkezi Yayınları, 1991.

MENGi, Mine. Divan Şiiri Yazıları, Ankara: Akçağ Yayını, 2000.

MENGi, Mine. "Nâbî́nin Şiirlerinde Urfa, istanbul, Halep" Millî Folklor, 2012, Yıl 24, Sayı 95, s. 45-53.

MUALLiM NACi. Osmanlı Şairleri, haz. (Cemal Kurnaz), ìstanbul: MEB Yayınları, 1995.

ONAY, Ahmet Talât. Açıklamalı Divan Şiiri Sözlüğü, (haz. Cemal Kurnaz), Ankara: Akçağ Yayınları, 2007.

PALA, İskender. Şahane Gazeller 3 Nâbî Nedim Şeyh Gâlib, İstanbul: Kapı Yayınları, 2010.

SARAÇ, M. A. Yekta. Klâsik Edebiyat Bilgisi Belâgat, ìstanbul: Gökkubbe, 2006.

ŞAFAK, Yakup. “SürurînninBahrü'l-Ma'ârifi ve Enîsü'l-Uşşâk ile Mukayesesi”, Basılmamış Doktora Tezi, Atatürk Üniversitesi SBE Erzurum, 1991.

ŞENTÜRK Ahmet Atillâ ve KARTAL, Ahmet. Eski Türk Edebiyatı Tarihi, ìstanbul: dergâh Yayınlar1, 2011. 
$116^{*}$ TAED 49

ibrahim GÜLTEKIN

TÂHiR-ÜL MEVLEVî. Edebiyat Lügati, ìstanbul: Enderun Kitabevi, 1973.

TARLAN, Ali Nihat. Necatî Beg Divanı, Ankara: Akçağ Yayınları, 1992.

ULUDAĞ, Süleyman. Tasavvuf Terimleri Sözlüğ̈̈, istanbul: Marifet Yayınları, 1995.

YILMAZ, Mehmet. Edebiyatımızda İslami Kaynaklı Sözler (Ansiklopedik Sözlük), İstanbul: Enderun Kitabevi, 1992.

Yeni Tarama Sözlüğü, (Düzenleyen Cem Dilçin), Ankara: TDK Yayınları, 1983.

ZAVOTÇU, Gencay. Dîvân Şiirinden Gazeller I, Dehhânî-Nesîmî-Şeyhî-Zâtî, Kocaeli, Umuttepe Kitabevi, 2012. 